ARCHIWA - KanCELARIE - ZBIORY

NR 6(8)/2015

\title{
V Warszawski Piknik Archiwalny
}

http://dx.doi.org/10.12775/AKZ.2015.013

WW

ubiegłym roku upłynęło pięć lat, odkąd wystartowaliśmy po raz pierwszy z Piknikiem Archiwalnym. Wtedy nie nazywał się „warszawski” i okupiony był ogromną tremą i brakiem doświadczenia w organizowaniu takiego przedsięwzięcia. Dzisiaj, świadomi zapotrzebowania na takie imprezy, a poza tym zżyci i zaprzyjaźnieni ze współorganizatorami, możemy śmiało twierdzić, że było warto. Jesteśmy rozpoznawalni i ludzie na nas czekają. Staramy się rozszerzać kierunki i wykorzystywać narzędzia, jakimi są media i elektronika, ale także cenimy opinie i radę każdej napotkanej osoby, która interesuje się naszą działalnością.

Piąta edycja Warszawskiego Pikniku Archiwalnego odbyła się 7 VI 2014 r. Miała zdecydowanie szerszy - w porównaniu do poprzedniczek - zasięg lokalizacyjny i przestrzenny, co postawiło przed organizatorami ogromne wyzwanie skoordynowania wspólnych działań. W sześciu punktach miasta miał być realizowany program, opracowany czasowo i logistycznie przez instytucje współorganizujące Piknik, tak by odwiedzający z zainteresowaniem go śledzili, poświęcili swój czas świadomie i wynieśli dużą dawkę satysfakcji. Już drugi raz Piknik „wyszedł” poza mury Pałacu Staszica i „usadowił się” w pięciu innych śródmiejskich lokalizacjach Warszawy: w Pałacu Raczyńskich, Muzeum Gazownictwa, Warszawskich Filtrach, Muzeum Drukarstwa i Teatrze Kamienica.

Przed Pałacem Staszica było gwarno i wesoło. Mikołaj Kopernik uśmiechał się i przytupywał w takt rytmicznych utworów dixielandowych, wykonywanych na pikniku już tradycyjnie przez zespół The Warsaw Dixielan- 
ders. Pogoda była zamówiona z dużym wyprzedzeniem, bo zamawiających na różne inne imprezy tego dnia było wielu. A wiadomo - stać w kolejce nikt nie lubi i jeszcze nie wiadomo, czy się dojdzie. Nam się jednak poszczęściło, co świadczy o tym, że „wyższe sfery” nas akceptują. Było wiele atrakcyjnych stoisk znanych firm, z bardzo różnym asortymentem: począwszy od żywności, miodu z ekologicznej pasieki, płodów rolnych z ekologicznych terenów podwarszawskich, po pamiątki rękodzielnicze, biżuterię i ceramikę artystyczną, a także płyty i kapelusze. Nie zabrakło również kilku stoisk wydawniczych.

Program imprez na dziedzińcu Pałacu zaplanowany był dużo wcześniej, kiedy nikt nie spodziewał się utrudnień zewnętrznych związanych z robotami drogowymi i dojazdem od ul. Świętokrzyskiej. Pomimo trudności wspaniały program plenerowy, opracowany przez Towarzystwo Przyjaciół Warszawy i Agencję Turystyczną Warsaw Tours, z ogromnym wkładem dwóch centrów ogrodniczych, został zrealizowany, ale w dużo skromniejszym zakresie. Mimo to chętnych do zakupu kwiatów balkonowych i rabatowych, ziół i kiełków nie zabrakło. $\mathrm{Na}$ dziedzińcu odbywały się niecodzienne warsztaty z hortiterapii, czyli leczenia roślinami ogrodowymi, a TPW pochwaliło się barwną i ładnie skomponowaną graficznie wystawą poświęconą ubiegłorocznym laureatom konkursu „Warszawa w kwiatach i zieleni”.

Wewnątrz Pałacu Piknik przybrał twarz naukowca, badacza i historyka, zaskoczył ogromem ciekawego materiału fotograficznego, dokumentalnego i audiowizualnego. Wielu prelegentów z szacownych instytucji nauki i kultury opowiadało historie o ludziach, czasach i zdarzeniach związanych z Warszawą i jej magią, których szczegóły drzemią w zasobach ich archiwów, muzeów, bibliotek i fundacji. Osobnym źródłem wrażeń były wystawy: w zabytkowych salach i wnętrzach Pałacu Staszica, przez swą wymowę tematyczną i konstrukcyjną, stanowiły wyjątkowo silny i niezapomniany akcent. Archiwum Polskiego Radia, z unikatowymi archiwaliami dźwiękowymi, a także z zaproszonym gościem w osobie Marka Niedźwieckiego, jak zwykle przykuwało wzrok, słuch i ciekawość wielu odwiedzających Piknik.

$\mathrm{Na}$ Pikniku można było uzyskać pożyteczne porady w sprawie prywatnych zbiorów, ich zabezpieczania i digitalizacji oraz możliwości przekazania do Archiwum Ośrodka KARTA.

Sale Lustrzana i Kinowa Pałacu Staszica były zarezerwowane dla przeprowadzania spotkań z zaproszonymi gośćmi, wygłaszania ciekawych referatów o tematyce archiwalnej oraz obejrzenia udostępnionych przez Filmotekę Na- 
rodową oraz TVP Warszawa materiałów filmowych. Materiały te, pochodzące z zasobów powyższych instytucji, były starannie wybrane z przebogatych zasobów i przygotowane tematycznie specjalnie na tegoroczny Piknik. Gościem specjalnym programu na Sali Lustrzanej był w tym roku Emilian Kamiński, znany aktor, reżyser i dyrektor Teatru Kamienica, którego bezpośredniość w zachowaniu, a także ogromna charyzma aktorska, reżyserska i społeczna wzbudziła szczere zainteresowanie i zapewniła niemałą widownię.

W tym roku patronat honorowy nad Piknikiem objęła Prezydent Miasta Stołecznego Warszawy Hanna Gronkiewicz-Waltz, naukowy - Naczelna Dyrekcja Archiwów Państwowych, a medialny Polskie Radio S.A., TVP Warszawa, TVP Historia, miesięczniki „Stolica” oraz „Wiedza i Życie”.

Program trwał siedem godzin. Przebiegał dynamicznie i liczba zwiedzających osób zwiększała się z każdą godziną. Odczuwało się zainteresowanie tematem, częste włączanie się do dyskusji i zadawanie pytań zarówno w czasie prezentacji w salach, jak i wizytacji ekspozycji. Ostatnim jego punktem był koncert w wykonaniu utalentowanej muzycznie młodzieży z Gminnego Ośrodka Kultury w Raszynie, która nie po raz pierwszy dawała pokaz w Pałacu Staszica. Jak zawsze, z dużym powodzeniem.

Słońce już zaczęło się powoli chylić ku zachodowi, kiedy kończyliśmy program piknikowy w Pałacu Staszica, ale ciągle jeszcze było dużo osób zainteresowanych... Pięcioletni jubilat pokazał wszystkim, co potrafi. Z pewnością, w miarę przybywania mu lat, rozbryka się na dobre. Będziemy śledzić, co z Niego wyrośnie.

Dorota Piętka-Hadata Polska Akademia Nauk Archiwum w Warszawie 


\section{KronikA}

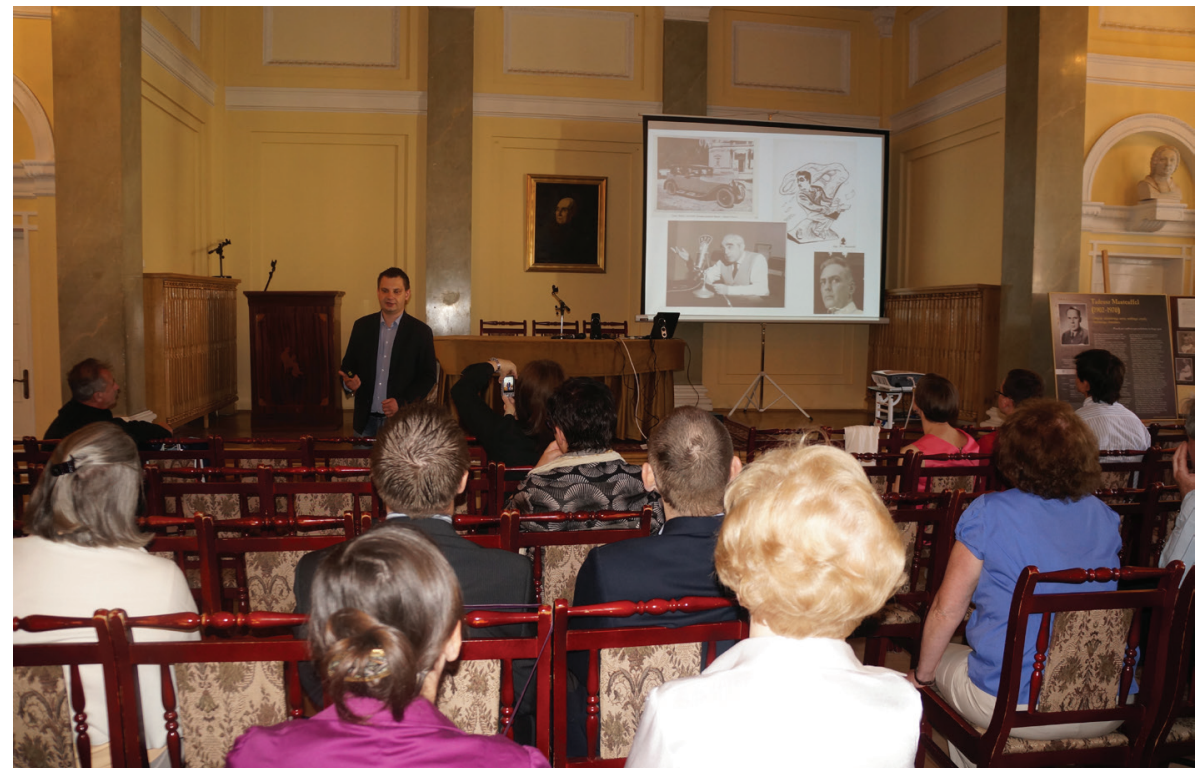

V Warszawski Piknik Archiwalny", autor Barbara Wiktorowska

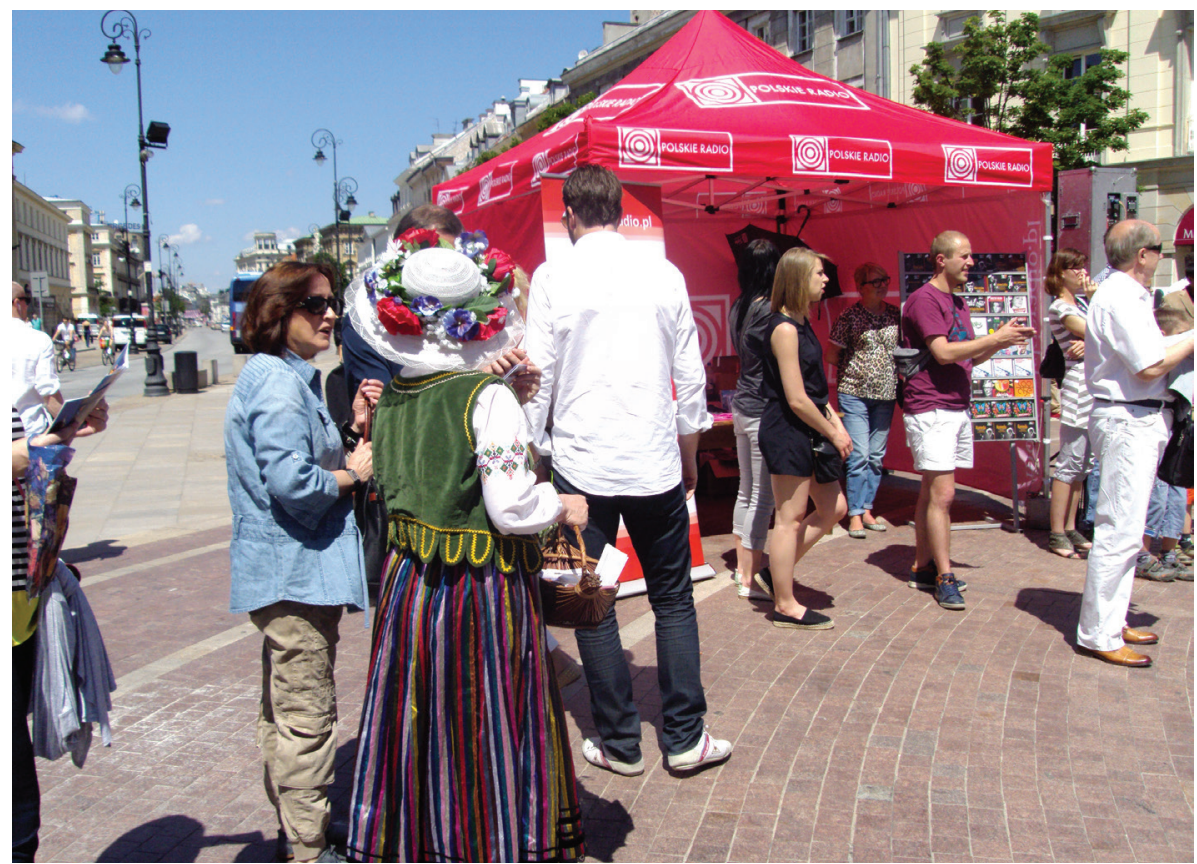

V Warszawski Piknik Archiwalny", autor Barbara Wiktorowska 
Kronika 279

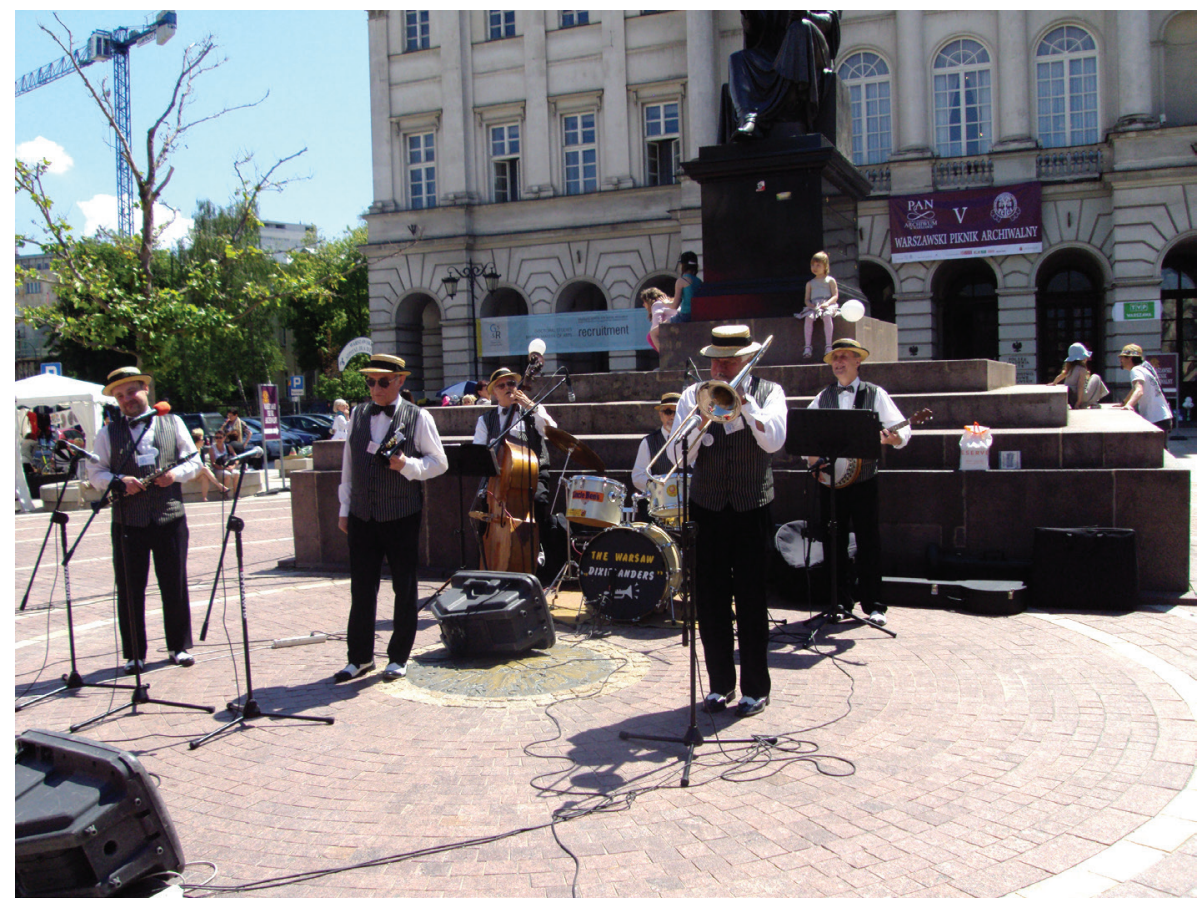

V Warszawski Piknik Archiwalny", autor Barbara Wiktorowska 